DOI: https://doi.org/10.47405/mjssh.v6i11.1159

\begin{tabular}{|c|c|}
\hline 4.581 & Malaysian Journal of Social Sciences and Humanities (MJSSH) \\
\hline $\begin{array}{l}\text { Malaysian Journal of } \\
\text { Social cciences and }\end{array}$ & Volume 6, Issue 11, November 2021 \\
\hline (MJ-SSH) & e-ISSN : 2504-8562 \\
\hline & $\begin{array}{l}\text { Journal home page: } \\
\text { www.msocialsciences.com }\end{array}$ \\
\hline
\end{tabular}

\title{
Hotel Choice of Muslim Consumers: Assessing the Unobserved Heterogeneity Among Gender
}

\author{
Nadzirah Rosli' ${ }^{1}$ Norbani Che-Haㄹ ${ }^{2}$ Ezlika M. Ghazali ${ }^{2}$ \\ 1Faculty of Economics and Management, Universiti Kebangsaan Malaysia, 43600 UKM Bangi, Selangor, Malaysia \\ 2Department of Marketing, Faculty of Business and Accountancy, Universiti Malaya, 50603 Kuala Lumpur, Malaysia
}

Correspondence: Nadzirah Rosli (nadzirah.rosli@ukm.edu.my)

\begin{abstract}
This paper aims to offer gendered insights on Malaysian Muslim tourist views of hotel choices. This study was designed to look at possible gender disparities in the perceived relevance of hotel attributes in developing emotional bonds with the hotel, that was enhanced by the brand credibility. The signaling theory were utilised to evaluate the relationships among the constructs. To validate the research model and hypotheses, the study used a partial least squares structural equation modelling (PLS-SEM) technique, and 474 Malaysian tourists were recruited to test the assumptions. The empirical results reveal that gender does not moderates the relationship between hotel attributes, brand credibility and brand attachment. Therefore, indicating that there were no differences observed between female and male Muslim tourists in their decision-making style. However, both male and female exhibited disparities in terms of strength on each construct. The findings of this study further provide a valuable implications and reference in terms of theoretical and practical perspective in the tourism destinations context, especially in Malaysia.
\end{abstract}

Keywords: hotel attributes, gender, brand credibility, brand attachment

\section{Introduction}

One of the most important aspects of a sustainability marketing plan is branding (Grubor \& Milovanov, 2017). Loyal customers are the driving force of brands, and they are an asset since they are willing to adopt and support the philosophy of their favourite brand, which might be a trigger to influence others. To put it another way, "once a majority accepts a notion, it becomes an unstoppable force" (Gordon, 2002).

Owning to branding, consumers may express their interests, attitudes, preferences, and general personality via the brands they use (Mcenally \& Chernatony, 1999). According to Cosper (2015), "your brand is your voice in the marketplace and your disruptive proposition. It is your chance to create something that will have a long-term influence. It is how you tell your stories, and it is critical to your success and survival". All these expressions highlight the significance of the brand-consumer connection.

In the hospitality sector, a hotel brand encompasses a wide range of physical and socio-psychological characteristics and values. The hotel's reputation for efficient service, quality, and consistency serves as the foundation for the brand. These qualities have a significant influence on customers' perceptions of 
brands and the meaning they place on them (Rosli et al., 2019). Because of the fast expansion of the hospitality sector, hotels are competing with one another to entice consumers to stay and use their services (Luturlean et al., 2018; Shafaei \& Mohamed, 2015). The underlying reason is that hotels are typically homogenous, hence strong brands are essential for meeting the difficulties of today's extremely dynamic marketplace. To increase their competitiveness, hotels must develop distinctive characteristics that set them apart from their competition. Understanding the requirements, interests, and behaviours of various tourist markets is thus critical in drawing them to destinations.

As tourists make their way for travelling purposes, they will, to some extent, require some form of lodging to relax and refresh themselves along the way. Thus, accommodation seemed to be a need, and while it may differ in size, facilities, and geographical location, they all serve the same purpose: to serve their customers and it plays an essential role in a tourist's entire experience at a destination (Fletcher et al., 2018).

Because most hotels are nearly identical, the tourist industry's need for high-quality products and services has grown (Anawade, 2016). Furthermore, the guest engagement is seen as a strategic asset of the organisation (Cavagnaro et al., 2018; Gruen et al., 2000), emphasising the significance of brand credibility and attachment in tourist hotel selection. Nonetheless, hotel brand credibility and brand attachment were seldom empirically studied. Hospitality academics have generally ignored the issues of brand credibility and brand attachment particularly in domain of service, in part because earlier works have mostly concentrated on delivering and recognising the significance of utilitarian features of hotels, which is insufficient in today's competitive market (Bougoure et al., 2016; Jeng, 2016; Kashif et al., 2018; Sheeraz et al., 2016; Tae \& King, 2011; Wang \& Yang, 2010).

Owning to this reason, Rosli et al. (2019) attempted to explore the impacts of hotel attributes on hotel's guest by nurturing brand credibility and brand attachment and its subsequent effects on word-of-mouth. According to the empirical findings, they found that hotel attributes are significantly contributing to brand credibility and brand attachment. Likewise, they also found supports on the effects of brand credibility on brand attachment, which in turn has a direct impact on word-of-mouth. Furthermore, they found that the association between hotel attributes with brand attachment were partially mediated by consumers' brand credibility.

It was also recognized that people's views of brand benefits varied by gender (Yang et al., 2020). Gender difference has received more attention than other personal characteristics (Wilborn et al., 2007) due to its capacity to understand consumer behaviour. The literature on gender and consumer behaviour has yielded two hypotheses: gender differences exist, and no gender differences exist. One study discovered that male and female behaviours differed greatly (Kolyesnikova et al., 2009), meanwhile no differences was observed between male and female tourists in predicting their outbound intention to revisit a destination (i.e., Glaslow) (Yang et al., 2020). This observation was concur with study conducted by Rahman (2019), which found no difference between male and female in their purchasing decision making.

Nonetheless, there was only little studies that attempted to explain on their findings. For instance, though Yang et al., (2020) found no difference between gender in their study, interestingly they found that if the number of sample size is larger, it is possible for the effects of gender as a moderator to be significant, as illustrated in the increased of the $\mathrm{R}_{2}$ value by $1.1 \%$. Therefore, though there is likely no universally agreed viewpoint, most consumer research concludes that "gender disparities exist" and a certain characteristics of tourist decision-making may differ from typical consumer decision-making behaviour, and gender findings in tourist studies may vary from most consumer behaviour research (Lin et al., 2014).

Thus, the primary goal of this study is to examine the moderating effects of gender on the relationship between hotel attributes and brand attachment that were enhanced through brand credibility. The study extends the previous study by Rosli et al., (2019) by presenting the heterogeneity between male and female groups between the hotel attributes, brand credibility and brand attachment. In fulfilling this objective, the present study offers a valuable insight to the body of knowledge especially in the tourism 
DOI: https://doi.org/10.47405/mjssh.v6i11.1159

marketing through the examination of gender role in the relationship of hotel attributes and brand attachment that was enhanced through brand credibility.

\section{Literature Review}

The present study worked based upon signaling theory in order to elucidates tourist behaviour in relation to hotel selection. According to this theory, the fundamental goal is to "signal" or express something about oneself to others, whether it is true or not. The hotelier serves as the signaler, while the consumer serves as the receiver, seeing and interpreting the signal. Because of the existence of information asymmetry in the hospitality sector, consumers must rely on trust and reputation information to guide their decision making (Zloteanu et al., 2018). Meanwhile, brand attachment and word-of-mouth were used to indicate feedback. Brand connection reflects the consumer's interest in the hotel's offers.

The link between the observed variables under investigation reveals certain variances in intensity that result from the effect of different factors, one of which is the consumer's gender. In order to build on this idea, this study offers four constructs, which are addressed below: hotel attributes, brand credibility, brand attachment, and gender as moderators.

\section{Hotel Attributes, Brand Credibility and Brand Attachment}

Product attributes are described as "properties or characteristics of a product which are intrinsic to it, or attached to it and concrete, observable, objectively measurable and relevant to choose among alternatives" (Tsung et al., 1988). According to Wuest, Tas, and Emenheiser (1996), perceptions of hotel attributes are the extent to which travellers believe that certain services and amenities are essential in enhancing their hotel stays' satisfaction. The present study defined hotel attributes as 'the degree to which tourist find various services and facilities offered by the hotel are important during their hotel stay" (Rosli et al., 2018).

Brand credibility on the other hand, stemmed from the concept of information asymmetries. In a situation where the market is imperfect (i.e., where the information about product quality was not made available to consumers) and asymmetric (i.e., where most of the information about the products or services were known by businesses), it is critical for firms to transmit trustworthy information to consumers (Erdem \& Swait, 1998). This implies that all the information that a company communicates to its customers regarding the status of their brand should be viewed as accurate and trustworthy. As a result, customer trust in a company's product promises would increase. In other words, a higher level of source credibility reflects positive indications of users' behavioural intentions (Tanha, 2020).

The concept of credibility was initially proposed by Hovland and Weiss (1953), who explores the communicators' credibility and later Erdem and Swait (1998) adapted the concept into the brand context. Based on the work of Erdem and Swait (2004), the present study defined brand credibility as "the extent tourist believe in products or services offered by a hotel based on the provided information". There are three dimensions of brand credibility which includes trustworthiness, expertise (Erdem et al., 2006; Tülin Erdem \& Swait, 1998, 2004), and attractiveness (Maathuis et al., 2004).

1) Trustworthiness-refers to a firm's readiness to deliver on its promises. It is associated to the extent to which an item is regarded as "a trustworthy source of information, products, services, and other issues" (Maathuis et al., 2004)

2) Expertise-refers to a firm's ability to deliver on its promises, which is associated to its knowledge and skills (Erdem \& Swait, 1998).

3) Attractiveness-refers to "the degree to which an object is appreciated by sympathetic behaviour, ambition, perseverance, smartness, and other personality-like characteristics" (Maathuis et al., 2004). 
Meanwhile, brand attachment is described as the amount to which an individual uses an object that he or she owns, expects to possess, or has owned to preserve his or her self-concept (Ball \& Tasaki, 1992). Brand attachment is defined in marketing literature as a consumer's long-term emotional relationship to a brand (Ghose \& Lowengart, 2013; Maathuis et al., 2004). According to Thomson, Macinnis, and Park (2005), it is conceived as "the emotional bonding, the degree of affection, passion and the connection to measure attachment toward specific brand".

Despite many efforts and research committed to explore the service management problems, little attention has been paid to evaluating service interactions from the customers' viewpoints. Practitioners, in particular, have not engaged enough with the potential inherent psychological drivers in the service interactions such as the emotional mechanism that consumers' experiences during the hotel stay (Chase \& Dasu, 2001). According to Gaur, Herjanto, and Makkar (2014), research on emotional concerns in marketing has grown in the previous decade. Marketing researchers have also become more aware of the role of emotion in customer decision making (Gaur et al., 2014). Previous research has shown that product or service attribution has an impact on brand attachment (Dolbec \& Chebat, 2013; Tae \& King, 2011; Vlachos et al., 2010) and the effect of brand credibility on attachment (Jeng, 2016; Tang et al., 2014).

In contrast, Rosli, Che-Ha, and Ghazali (2020) found no support on the association between hotel attributes and brand attachment, however interestingly they found that Muslim visitors' hotel choices are interconnected in such a manner that brand credibility completely mediates the influence of hotel attributes on brand attachment, validating the assumption that when consumers acquire the impression that the hotel is trustworthy, a stronger attachment is therefore expected to be established through the hotel attributes.

\section{The Moderating Role of Gender}

Gender is a unique segmentation variable that may be examined effectively. It may, however, be made up of multiple subculture groupings. Gender influences consumer behaviour in a variety of research since it is so closely related to consumption (Yang et al., 2020). In terms of purchasing habits, males and females differ (Dholakia, 1999). Males, in particular, held opposing values when it came to "effective" purchasing, contrary to females (Bakewell \& Mitchell, 2003, 2004, 2006). Males frequently shopped fast owing to their priority over time, but ladies enjoy spending more time and efforts on shopping because they exhibited more interests in shopping. Furthermore, men were less likely to shop than women (Dholakia, 1999).

In the domain of tourism, female and male visitors have distinct preferences in terms of travelling activities and intention to return (Abubakar et al., 2017; Akinci \& Aksoy, 2019). Females, for example, exhibited a stronger proclivity to travel for leisure than males (Collins \& Tisdell, 2002). Overall, the outcomes of these research revealed that males and females differed in terms of their purchasing style, travel style, and behaviour. Therefore, the following hypothesis was developed:

Hypothesis 1: The strength of relationship between hotel attributes and brand attachment is different between female and male.

Hypothesis 2: The strength of relationship between hotel attributes and brand credibility is different between female and male.

Hypothesis 3: The strength of relationship between brand credibility and brand attachment is different between female and male.

Hypothesis 4: The strength of brand credibility in mediating the relationship between hotel attributes and brand attachment is different between female and male. 
Figure 1. Research Framework

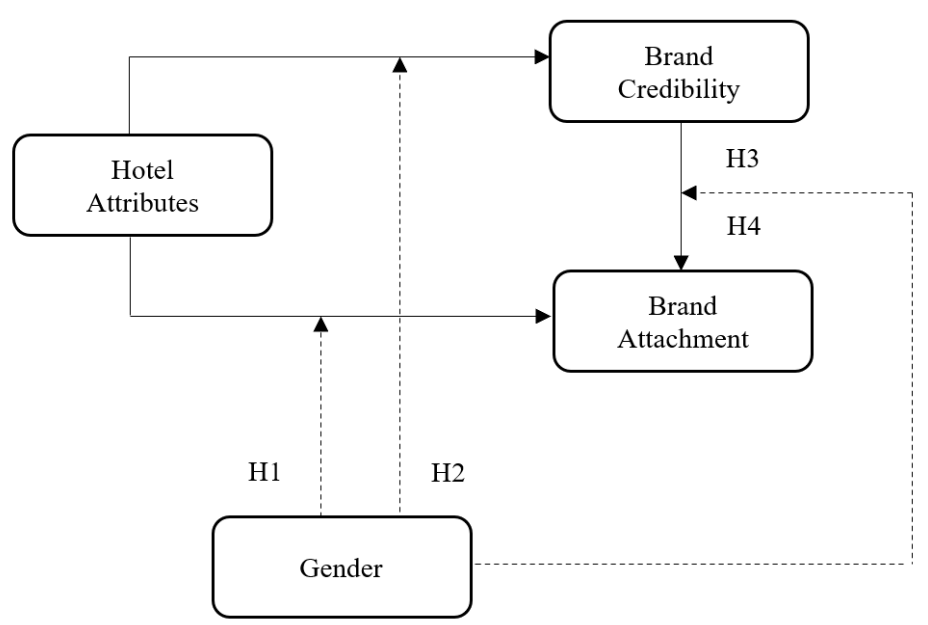

\section{Research Methodology}

\section{Data Collection and Samples}

A non-probability sampling: the purposive sampling was employed for data collection through a survey questionnaire. The target sample's main criterion was, Muslim tourists in Malaysia, whom previously had experienced staying in a hotel recently. Muslim travellers represented our target respondents due to number of reasons. First, it is noted that there was an increase in halal consumers' purchasing power which stemmed from the increased amount of Muslim population (Thomson Reuters, 2017). Based on the statistic provided by Thompson Reuters, Muslim travel market was recorded as the second largest just behind China and surpassed the United States. However, the Muslim travel spend is estimated to fall by $70 \%$ due to COVID-19 pandemic. Nonetheless, it is estimated to grow at a 5-year CAGR of $1.4 \%$ and reaching \$208 billion in 2024 (Dinar Standard, 2020). This implies that though the demand falls short at the moment, but the demand for Muslim travel requirements is continuously increasing in a long-term, which has been attributed to an increase in spending power among Muslim consumers. Secondly, it is also noted that studies that assessing travel motivations among Muslim has only received a limited attention, which is in contrast with travel motivations among Western populations. This indicates a failure to recognise the genuine demands of Muslim customers (Battour, Battor, \& Ismail, 2012). Working based on this background, the present study seeks to look into drivers and outcomes of hotel choice, particularly among Muslim consumer in Malaysia. A total of 474 valid responses were used for further analysis. Table 1 illustrates the profile of respondents for the present study.

Table 1: Summary of Sample Demographic Profile

\begin{tabular}{llrr}
\hline \multicolumn{2}{l}{ Demographic Characteristics } & Frequency & Percent \\
\hline Gender & Male & 254 & 53.6 \\
& Female & 220 & 46.4 \\
\hline Age & $20-29$ years old & 377 & 79.5 \\
& $30-39$ years old & 56 & 11.8 \\
& $40-49$ years old & 35 & 7.4 \\
& $50-59$ years old & 5 & 1.1 \\
& 60 years old \& above & 1 & .2 \\
\hline
\end{tabular}


DOI: https://doi.org/10.47405/mjssh.v6i11.1159

\begin{tabular}{llrr}
\hline Marital Status & Single & 366 & 77.2 \\
& Married without children & 28 & 5.9 \\
Married with children & 77 & 16.2 \\
& Divorced/Separated/Widowed & 3 & .6 \\
\hline Education & SPM & 34 & 7.2 \\
& STPM/Diploma/College & 123 & 25.9 \\
Bachelor Degree/Professional Degree & 299 & 63.1 \\
& Postgraduate Degree & 18 & 3.8 \\
\hline Monthly Income & Less than RM1,999 & 254 & 53.6 \\
& RM2,000 - RM3,999 & 137 & 28.9 \\
& RM4,000 - RM5,999 & 53 & 11.2 \\
RM6,000 - RM7,999 & 14 & 3.0 \\
RM8,000 - RM9,999 & 8 & 1.7 \\
& RM10,000 and above & 8 & 1.7 \\
\hline
\end{tabular}

\section{Measures}

The questionnaires were divided into several sections. In the first section, questions that are related to the respondents' travel behaviour were addressed. Secondly, the respondents were asked to rate their response on the questions that are related to the hotel attributes which were adapted from numerous literatures (Battour, Ismail, Battor, \& Awais, 2014; Chu \& Choi, 2000; Juwaheer, 2004; Poon \& Low, 2005; Saad, Ali, \& Abdel-Ati, 2014). Third, the respondents were asked to rate their response on the questions that are related to brand credibility construct which were adapted from Tülin Erdem and Swait (2004), Ohanian (1990), and Wang and Yang (2010) and brand attachment construct which were adapted from Hemsley-Brown and Alnawas (2016). These constructs were anchored with sevenpoint Likert scale. The final section of the questionnaire asked respondents to answer questions that are related to their demographic profile.

\section{Data Analysis}

To assess the model, Partial Least Squares - Structural Equation Modeling (PLS-SEM), a variancebased structural equation modelling, was utilised. The PLS was chosen because (1) the study model was rather complicated, and (2) a component of the structural model was a formative measurement construct. As a result, the usage of PLS is recommended (Hair et al., 2016). SmartPLS 3.3.3 software was used in this research.

\section{Results and Discussion}

\section{Measurement Model - Reflective Constructs}

The item loadings, average variance extracted (AVE) and composite reliability (CR) were assessed to evaluate the convergent validity and reliability for all latent variables in the reflective measurement model (Hair et al., 2017). As observed in Table 2, all latent variables obtained satisfactory item loadings (i.e, more than 0.708)(Hair et al., 2014) and obtained convergent validity since the AVEs and CRs are well above the required threshold of 0.50 and 0.70 respectively. 
DOI: https://doi.org/10.47405/mjssh.v6i11.1159

Table 2: Convergent Validity (Reflective Constructs)

\begin{tabular}{|c|c|c|c|c|c|}
\hline First Order Construct & Second Order Construct & Item & Loadings & $\mathbf{C R}$ & AVE \\
\hline \multirow[t]{5}{*}{ Brand Passion } & & BA1 & 0.860 & 0.954 & 0.807 \\
\hline & & BA2 & 0.915 & & \\
\hline & & BA3 & 0.917 & & \\
\hline & & BA4 & 0.899 & & \\
\hline & & BA5 & 0.902 & & \\
\hline \multirow[t]{5}{*}{ Self-Brand Connection } & & BA6 & 0.911 & 0.952 & 0.800 \\
\hline & & BA7 & 0.852 & & \\
\hline & & BA8 & 0.910 & & \\
\hline & & BA9 & 0.898 & & \\
\hline & & BA10 & 0.896 & & \\
\hline \multirow[t]{7}{*}{ Brand Affection } & & BA11 & 0.917 & 0.946 & 0.813 \\
\hline & & BA12 & 0.913 & & \\
\hline & & BA13 & 0.891 & & \\
\hline & & BA14 & 0.885 & & \\
\hline & Brand Attachment & BP & 0.949 & 0.955 & 0.876 \\
\hline & & SBC & 0.950 & & \\
\hline & & BAFF & 0.909 & & \\
\hline
\end{tabular}

Table 2: Cont.

\begin{tabular}{lccccc}
\hline First Order Construct & Second Order Construct & Item & Loadings & CR & AVE \\
\hline Expertise & & BC1 & 0.898 & 0.904 & 0.825 \\
Trustworthiness & BC2 & 0.919 & & \\
& & BC3 & 0.862 & 0.930 & 0.728 \\
& & BC4 & 0.851 & & \\
Attractiveness & BC5 & 0.855 & & \\
& BC6 & 0.852 & & \\
& & BC7 & 0.845 & & \\
& BC8 & 0.917 & 0.946 & 0.855 \\
& Brand Credibility & BC9 & 0.933 & & \\
& & BC10 & 0.923 & & \\
& & EXP & 0.831 & 0.922 & 0.799 \\
& TRS & 0.968 & & \\
\hline
\end{tabular}

Notes: $\mathrm{BP}=$ Brand Passion, $\mathrm{SBC}=$ Self-Brand Connection, $\mathrm{BAFF}=$ Brand Affection, $\mathrm{EXP}=$ Expertise, TRS $=$ Trustworthiness, ATT $=$ Attractiveness

Subsequently, the discriminant validity was assessed by heterotrait-monotrait correlation ratio (HTMT) (Franke \& Sarstedt, 2018). The discriminant validity is established if all the values of HTMT are smaller or equal to 0.85 . Table 3 demonstrated that the HTMT value is less than 0.85 , thus implying that the discriminant validity was established in the study.

Table 3: Discriminant Validity (Heterotrait-Monotrait Correlation Ratio)

\begin{tabular}{lcc}
\hline Construct & Brand Credibility & Brand Attachment \\
\hline Brand Credibility & 0.643 & \\
Brand Attachment & & \\
\hline
\end{tabular}




\section{Measurement Model - Formative Construct}

Subsequently, for the formative construct, the convergent validity is evaluated through the collinearity (VIF) and the significance of weight and loading for each items (Hair et al., 2017). First, the assessment of measurement model for formative construct was conducted through the examination of multi-collinearity between indicators. A high level of multicollinearity indicates that some items may be redundant. As observed in Table 4, all the items satisfy the VIF values, and they are consistently below the threshold value of 0.50 (Hair et al., 2017). Thus, it can be concluded that collinearity does not reach critical levels and it is not a concern for the estimation of the PLS path model.

The significance and relevance of the formative indicators were also evaluated. As observed in Table 4, some of the indicators possessed a significant weight, while some possessed an insignificant weight. However, an insignificant weight should not be regarded as poor measurement quality, but the absolute contribution of the formative indicators should be evaluated via the outer loading. Further observation on Table 4 indicates that the outer loading was significant. Hence, the study concluded that all the items were valid and reliable.

Table 4: Convergent Validity (Formative Construct)

\begin{tabular}{|c|c|c|c|c|c|c|c|}
\hline $\begin{array}{l}\text { First } \\
\text { Order } \\
\text { Construct }\end{array}$ & $\begin{array}{l}\text { Second } \\
\text { Order } \\
\text { Construct }\end{array}$ & Items & Scale & Weights & $\begin{array}{c}\text { t-value } \\
\text { (weight) }\end{array}$ & $\begin{array}{l}\text { t-value } \\
\text { (loading) }\end{array}$ & VIF \\
\hline \multirow{7}{*}{$\begin{array}{l}\text { Essential } \\
\text { Facilities }\end{array}$} & & HA1 & Formative & 0.332 & 3.177 & 8.302 & 1.922 \\
\hline & & HA2 & & 0.120 & 0.926 & 5.093 & 2.691 \\
\hline & & HA10 & & 0.209 & 1.509 & 5.417 & 3.058 \\
\hline & & HA11 & & -0.136 & 0.952 & 3.698 & 3.567 \\
\hline & & HA12 & & -0.096 & 0.675 & 3.686 & 3.233 \\
\hline & & HA13 & & -0.018 & 0.147 & 3.818 & 2.178 \\
\hline & & HA14 & & 0.000 & 0.003 & 3.730 & 2.484 \\
\hline \multirow{6}{*}{$\begin{array}{l}\text { Culture- } \\
\text { Compliant } \\
\text { Facilities }\end{array}$} & & HA15 & Formative & 0.051 & 0.392 & 6.428 & 1.806 \\
\hline & & HA16 & & 0.059 & 0.478 & 3.243 & 1.894 \\
\hline & & HA17 & & -0.310 & 2.366 & 1.352 & 2.161 \\
\hline & & HA18 & & -0.126 & 1.533 & 2.874 & 1.530 \\
\hline & & HA19 & & 0.039 & 0.382 & 5.458 & 1.761 \\
\hline & & HA20 & & 0.598 & 5.115 & 10.365 & 1.995 \\
\hline \multirow{13}{*}{$\begin{array}{l}\text { In-room } \\
\text { Facilities }\end{array}$} & & HA3 & Formative & 0.051 & 0.303 & 2.602 & 2.365 \\
\hline & & HA4 & & 0.479 & 3.744 & 6.269 & 1.773 \\
\hline & & HA5 & & -0.289 & 2.093 & 3.098 & 2.508 \\
\hline & & HA6 & & -0.036 & 0.302 & 4.599 & 1.904 \\
\hline & & HA7 & & -0.138 & 1.034 & 3.489 & 2.139 \\
\hline & & HA8 & & 0.154 & 1.211 & 4.974 & 2.429 \\
\hline & & HA9 & & 0.191 & 1.710 & 5.138 & 2.254 \\
\hline & Hotel & Essential & Formative & 0.447 & 2.240 & 14.846 & 2.656 \\
\hline & Attributes & Facilities & & & & & \\
\hline & & Culturally & & & & & \\
\hline & & Compliant & & 0.344 & 2.121 & 9.565 & 1.662 \\
\hline & & Facilities & & & & & \\
\hline & & $\begin{array}{l}\text { In-Room } \\
\text { Facilities }\end{array}$ & & 0.300 & 1.535 & 11.709 & 2.563 \\
\hline
\end{tabular}

\section{Multi-Group Analysis}

First and foremost, when engaging in multigroup analysis (MGA), it was critical to ascertain that the number of observations in each group meets the rule of thumb for minimum sample size. According to the power analysis results using $\mathrm{G}^{*}$ Power, 64 observations per group were needed to detect $\mathrm{R}_{2}$ values of about 0.25 at a significance level of $5 \%$ and a power level of $80 \%$. Therefore, the group-specific 
sample sizes for both male $(n=254)$ and female $(n=220)$ were considered sufficiently large with approximately equal sample sizes. Notably, this dataset did not have issues with missing values or reliability and validity. As a result, STEP 1 namely configural variance was established.

Prior to performing the MGA, measurement invariance of composites (MICOM) was used to test the measurement invariance of a model across the two groups (Joseph F. Hair et al., 2016; Henseler et al., 2016). The compositional invariance was determined by comparing the correlation $\mathrm{c}$ between the first and second groups' composite scores and the 5\% quantile. When the quantile was less than or equal to the correlation c for all constructs, compositional invariance was attained. Compositional invariance had been established for all multi-item constructs in the model, as illustrated in the Table 2.

Furthermore, if the mean and variance original difference fell between 2.5 and 97.5 per cent boundaries, the full invariance was attained. In addition, when only one of the two (mean or variance) original difference fell between 2.5 and 97.5 per cent boundaries, the partial invariance was attained. As observed in Table 5, the partial measurement invariance was attained on all constructs for both groups, indicating a need to compare differences between female and male group using MGA. The pvalue ( $p>0.05)$ further supported these findings.

Table 5: Results of invariance measurement testing

\begin{tabular}{|c|c|c|c|c|c|c|c|c|c|}
\hline \multirow[b]{2}{*}{ Constructs } & \multirow[b]{2}{*}{$\begin{array}{l}\text { Configural } \\
\text { Invariance }\end{array}$} & \multicolumn{2}{|c|}{$\begin{array}{c}\text { Compositional } \\
\text { Invariance } \\
(\text { Correlation = 1) } \\
\end{array}$} & \multirow{2}{*}{$\begin{array}{c}\text { Partial } \\
\text { Measurement } \\
\text { Invariance } \\
\text { Established }\end{array}$} & \multicolumn{2}{|c|}{ Equal Mean Value } & \multicolumn{2}{|c|}{ Equal Variance } & \multirow{2}{*}{$\begin{array}{c}\text { Full } \\
\text { Measurement } \\
\text { Invariance } \\
\text { Established }\end{array}$} \\
\hline & & $C=1$ & $\begin{array}{c}\text { quartile of } \\
\text { the } \\
\text { empirical } \\
\text { distributio } \\
n \text { of } c\end{array}$ & & Differences & $\begin{array}{c}\text { Confidence } \\
\text { Interval }\end{array}$ & Differences & $\begin{array}{c}\text { Confidence } \\
\text { Interval }\end{array}$ & \\
\hline $\begin{array}{l}\text { Hotel } \\
\text { Attributes }\end{array}$ & Yes & 0.818 & 0.692 & Yes & -0.131 & $\begin{array}{c}-0.179 \\
0.184]\end{array}$ & -0.155 & $\begin{array}{c}-0.499 \\
0.488]\end{array}$ & Yes \\
\hline $\begin{array}{l}\text { Brand } \\
\text { Credibility }\end{array}$ & Yes & 1.000 & 1.000 & Yes & -0.196 & $\begin{array}{c}{[-0.180} \\
0.180]\end{array}$ & 0.112 & $\begin{array}{c}{[-0.279} \\
0.288]\end{array}$ & No \\
\hline $\begin{array}{l}\text { Brand } \\
\text { Attachment }\end{array}$ & Yes & 1.000 & 1.000 & Yes & -0.490 & $\begin{array}{c}{[-0.182} \\
0.181]\end{array}$ & 0.251 & $\begin{array}{c}{[-0.268} \\
0.260] \\
\end{array}$ & No \\
\hline
\end{tabular}

The outcome of the permutation test was then analysed. The presence of significant differences between groups were demonstrated by a p-value less than 0.10 . As observed in Table 6 , it is found that there were no significant differences between the two groups' (female and male). This indicated that the two groups are similar. Thus, hypotheses 1, 2, 3 and 4 are not supported.

Table 6: Summary of Permutation Test for Gender

\begin{tabular}{|c|c|c|c|c|c|}
\hline \multirow{2}{*}{ Hypothesis } & \multirow{2}{*}{ Path } & \multicolumn{3}{|c|}{ Path Coefficient } & \multirow{2}{*}{$\begin{array}{c}\text { p-value } \\
\text { Permutation }\end{array}$} \\
\hline & & Female & Male & Difference & \\
\hline 1 & $\mathbf{H A}>\mathbf{B A}$ & 0.061 & -0.021 & 0.082 & 0.417 \\
\hline 2 & $\mathbf{H A}>\mathbf{B C}$ & 0.433 & 0.509 & -0.076 & 0.421 \\
\hline 3 & $\mathbf{B C}>\mathbf{B A}$ & 0.618 & 0.590 & 0.028 & 0.720 \\
\hline 4 & $\mathbf{H A}>\mathbf{B C}>\mathbf{B A}$ & 0.268 & 0.300 & -0.032 & 0.662 \\
\hline
\end{tabular}

Notes: $\mathrm{HA}=$ Hotel Attributes, $\mathrm{BA}=$ Brand Attachment, $\mathrm{BC}=$ Brand Credibility

\section{Conclusion}

The main objective of this study was to examine the moderating effects of gender on the relationship between hotel attributes and brand attachment that were enhanced through brand credibility. Based on the findings, it is demonstrated that gender does not pose any effect on explaining the relationship between hotel attributes and brand attachment, as well as brand credibility. Therefore, the role of gender in predicting the Muslim tourists' hotel choice in Malaysia by fostering the brand attachment and brand credibility was insignificant. This finding concurs with the previous research that also found 
that there was no significant difference between gender in destination decisions (Lin et al., 2014; Yang et al., 2020) .

Though that there was no significant difference between female and male, however our findings also indicated that the effect of hotel attributes on brand attachment, as well as the effect of brand credibility on brand attachment are stronger for female rather than males. This suggests that female customers are more likely to establish a brand attachment, which is described as "the emotional quality and strength of an individual's relationship with an object" (Park et al., 2010; Park et al., 2006; Thomson, MacInnis, et al., 2005). Therefore, it is consistent with the previous findings by Kasambala, Kempen, and Labschagne (2018) that suggested some emotions could actually encourage rather than discourage consumers from purchasing especially among women. Women, on average, are also more likely than males to communicate their emotional moods (Rosli et al., 2018).

On the other hand, we also found that the effect of hotel attributes on brand credibility are stronger for male as compared with female. Furthermore, when the link between hotel attributes and brand attachment is strengthened through brand credibility, males benefit more than females. This concurs with the previous literature that suggests while women are more internally focused, men on the other hand ought to be externally focused (Lakshmi et al., 2017). They also suggested that men tend to buy instrumental items whereas women tend to buy symbolic and self-expressive goods. The idea of credibility is connected to "the degree to which an item is regarded as a reliable source of information, products, and services" (Keller \& Aaker, 1998), which comprises of trustworthiness, expertise (Erdem \& Swait, 1998, 2004; Erdem, Swait, \& Valenzuela, 2006) and attractiveness (Maathuis et al., 2004). This is consistent with the findings of Sallam and Wahid (2012), who found that endorser attractiveness had a greater influence on male consumers' attitudes about advertisements than endorser expertise. Similarly, male consumers chose trustworthy brands, particularly those with a high level of neuroticism (Mulyanegara et al., 2009).

\section{Limitation and Future Research}

While this study aims to explore the role of gender in explaining the link between hotel attributes and brand attachment, which was increased by brand credibility, it fails to depict the differences that are predicted to exist between male and female tourists. Perhaps employing larger sample sizes or focusing especially on specific age groups might render statistical differences.

Moreover, since the current study was centred to Malaysian Muslim tourists, future research could explore broadening the research samples to include international Muslim visitors. As they are from different cultures, they are likely to have different attitudes and preferences when it comes to hotel selection. Future research may compare the two and undertake cross-sectional analysis.

Finally, this study specifically looks at possible gender variations in the perceived relevance of hotel features in developing an emotional relationship with the hotel, which was enhance by brand credibility. This study will contribute to the literature on hospitality by investigating the impact of gender, with the assumption that the benefits of hotel characteristics in developing connection with the customer are stronger on women than males. Under the current global competitive market, the biggest challenge for companies is to remain profitable and maintain relevant, with this information, hotel owners will be able to develop more creative and successful marketing campaigns that highlight gendered insights.

\section{References}

Abubakar, A. M., Ilkan, M., Meshall Al-Tal, R., \& Eluwole, K. K. (2017). eWOM, revisit intention, destination trust and gender. Journal of Hospitality and Tourism Management, 31, 220-227. https://doi.org/10.1016/j.jhtm.2016.12.005

Akinci, S., \& Aksoy, S. (2019). The impact of service recovery evaluation on word-of-mouth intention: A moderated mediation model of overall satisfaction, household income and gender. Tourism 
Management Perspectives, 31(1), 84-94. https://doi.org/10.1016/j.tmp.2019.05.002

Anawade, P. A. (2016). Customer Satisfaction With Reference To Individual Spending Pattern on Hotel Industry : a Case Study for Hotel Silver Palace. International Journal of Management, 7(7), 336343.

Bakewell, C., \& Mitchell, V. W. (2003). Generation Y female consumer decision-making styles. International Journal of Retail \& Distribution Management, 31(2), 95-106. https://doi.org/10.1108/09590550310461994

Bakewell, C., \& Mitchell, V. W. (2004). Male consumer decision-making styles. International Review of Retail, Distribution and Consumer Research, 14(2), 223-240. https://doi.org/10.1080/0959396042000178205

Bakewell, C., \& Mitchell, V. W. (2006). Male versus female consumer decision making styles. Journal of Business Research, 59(12), 1297-1300. https://doi.org/10.1016/j.jbusres.2006.09.008

Ball, A. D., \& Tasaki, L. H. (1992). The Role and measurement of attachament in consumer Behavior. Journal of Consumer Psychology, 1(2), 155-172. https://doi.org/10.1207/s15327663jcp0102

Battour, M., Ismail, M. N., Battor, M., \& Awais, M. (2014). Current Issues in Islamic tourism: an empirical examination of travel motivation and satisfaction in Malaysia. Current Issues in Tourism, 20(1), 50-67. https://doi.org/10.1080/13683500.2014.965665

Battour, M. M., Battor, M. M., \& Ismail, M. N. (2012). The Mediating Role of Tourist Satisfaction: A Study of Muslim Tourists in Malaysia. Journal of Travel \& Tourism Marketing, 29(February 2015), 279-297. https://doi.org/10.1080/10548408.2012.666174

Bougoure, U. S., Russell-Bennett, R., Fazal-E-Hasan, S., \& Mortimer, G. (2016). The impact of service failure on brand credibility. Journal of Retailing and Consumer Services, 31, 62-71. https://doi.org/10.1016/j.jretconser.2016.03.006

Cavagnaro, E., Düweke, A., \& Melissen, F. (2018). The host-guest relationship is the key to sustainable hospitality: Lessons learned from a Dutch case study. Hospitality and Society, 8(1). https://doi.org/10.1386/hosp.8.1.23_1

Chase, R., \& Dasu, S. (2001). Want to Perfect Your Company's Service? Use Behavioral Science. In Harvard Business Review on Customer Relationship Management (pp. 67-84). Harvard Business School Press. https://books.google.com/books?id=cF4pOm4Vs-sC\&pgis=1

Chu, R. K. S., \& Choi, T. (2000). An importance-performance analysis of hotel selection factors in the Hong Kong hotel industry: a comparison of business and leisure travellers. Tourism Management, 21(4), 363-377. https://doi.org/10.1016/S0261-5177(99)00070-9

Collins, D., \& Tisdell, C. (2002). Gender and differences in travel life cycles. Journal of Travel Research, 41(2), 133-143. https://doi.org/10.1177/004728702237413

Cosper, A. (2015). It's not you, It's your Story: Why Branding Matters.pdf. Entrepreneur Media, Inc.

Dholakia, R. R. (1999). Going shopping: Key determinants of shopping behaviors and motivations. International Journal of Retail \& Distribution Management, 27(4), 154-165. https://doi.org/10.1108/09590559910268499

Dinar Standard. (2020). State of the Global Islamic Economy Report 2020/2021. In Salaam Gateway. https://cdn.salaamgateway.com/special-coverage/sgie19-20/full-report.pdf

Dolbec, P. Y., \& Chebat, J. C. (2013). The Impact of a Flagship vs. a Brand Store on Brand Attitude, Brand Attachment and Brand Equity. Journal of Retailing, 89(4), 460-466. https://doi.org/10.1016/j.jretai.2013.06.003

Erdem, T., \& Swait, J. (2004). Brand Credibility, Brand Consideration, and Choice. Journal of Consumer Research, 31(1), 191-198. https://doi.org/10.1086/383434

Erdem, T., Swait, J., \& Valenzuela, A. (2006). Brands as Signals: A Cross-Country Validation Study. Journal of Marketing, 70(1), 34-49. https://doi.org/10.1509/jmkg.2006.70.1.34

Erdem, T. T., \& Swait, J. (1998). Brand Equity as a Signaling Phenomena. Journal of Consumer Psychology, 7(2), 131-157. https://doi.org/10.1207/s15327663jcp0702_02

Fletcher, J., Fyall, A., Gilbert, D., \& Wanhill, S. (2018). Tourism : Principles and Practice (6th Editio). Harlow, England: Pearson.

Franke, G., \& Sarstedt, M. (2018). Heuristics versus statistics in discriminant validity testing: A comparison of four procedures. Internet Research, 1-31.

Gaur, S. S., Herjanto, H., \& Makkar, M. (2014). Review of emotions research in marketing , $2002-$ 2013. Journal of Retailing and Consumer Services, 21(6), 917-923. https://doi.org/10.1016/j.jretconser.2014.08.009 
Ghose, S., \& Lowengart, O. (2013). Consumer choice and preference for brand categories. Journal of Marketing Analytics, 1(1), 3-17. https://doi.org/10.1057/jma.2012.1

Gordon, W. (2002). Brand Green: Mainstream or Forever Niche? Brand Green: Mainstream or Forever Niche?, 1(1).

Grubor, A., \& Milovanov, O. (2017). Brand Strategies in the Era of Sustainability. Interdisciplinary Description of Complex Systems. https://doi.org/10.7906/indecs.15.1.6

Gruen, T. W., Summers, J. O., \& Acito, F. (2000). Relationship Marketing Activities, Commitment, and Membership Behaviors in Professional Associations. Journal of Marketing, 64(3), 34-49. https://doi.org/10.1509/jmkg.64.3.34.18030

Hair, J. F., Hult, G. T. M., Ringle, C. M., \& Sarstedt, M. (2017). A Primer on Partial Least Squares Structural Equation Modeling (PLS-SEM). Second Edition. In Sage Publications (2nd ed). Sage Publications.

Hair, Joe F., Sarstedt, M., Hopkins, L., \& Volker, G. K. (2014). Partial least squares structural equation modeling (PLS-SEM). European Business Review, 26(2), 106-121. https://doi.org/10.1108/EBR10-2013-0128

Hair, Joseph F., Hult, G. T. M., Ringle, C. M., \& Sarstedt, M. (2016). A Primer on Partial Least Squares Structural Equation Modeling (PLS-SEM) (2nd ed.). Thousand Oaks: Sage.

Hemsley-Brown, J., \& Alnawas, I. (2016). Service quality and brand loyalty. International Journal of Contemporary Hospitality Management, 28(12), 2771-2794. https://doi.org/10.1108/IJCHM-092015-0466

Henseler, J., Hubona, G., \& Ray, P. A. (2016). Using PLS path modeling in new technology research: Updated guidelines. Industrial Management and Data Systems, 116(1), 2-20. https://doi.org/10.1108/IMDS-09-2015-0382

Hovland, C. I., \& Weiss, W. (1953). The influence of source credibility on communication effectiveness. Public Opinion Quarterly, 15, 635-650. https://doi.org/10.1086/266350

Jeng, S. P. (2016). The influences of airline brand credibility on consumer purchase intentions. Journal of Air Transport Management, 55, 1-8. https://doi.org/10.1016/j.jairtraman.2016.04.005

Juwaheer, T. D. (2004). Exploring international tourists' perceptions of hotel operations by using a modified SERVQUAL approach - a case study of Mauritius. Managing Service Quality, 14(5), 350-364. https://doi.org/10.1108/09604520410557967

Kasambala, J., Kempen, E., \& Labschagne, J. (2018). The role of integral emotions in female consumers' clothing purchasing decision. Retail and Marketing Review, 14(2), 17-28.

Kashif, M., Fernando, P. M. P., Samad, S., \& Thurasamy, R. (2018). Finding greener grass on the other side of hill: Examining donor perceived brand equity in a moderating role of brand credibility. Asia Pacific Journal of Marketing and Logistics, 30(4), 988-1012. https://doi.org/10.1108/APJML-10-2017-0231

Keller, K. L., \& Aaker, D. A. (1998). The Impact of Corporate Marketing on a Company's Brand Extensions. Corporate Reputation Review, 1(4), 356-378. https://doi.org/10.1057/palgrave.crr.1540057

Kolyesnikova, N., Dodd, T. H., \& Wilcox, J. B. (2009). Gender as a moderator of reciprocal consumer behavior. Journal of Consumer Marketing, 26(3), 200-213. https://doi.org/10.1108/07363760910954136

Lakshmi, V. V., Aparanjini, Niharika, D., \& Lahari, G. (2017). Impact of Gender on Consumer Purchasing Behavior. IOSR Journal of Business and Management, 19(8), 33-36. https://doi.org/10.9790/487X-1908053336

Lin, J.-H., Lee, S.-J., Ching, Y., Lee, W.-H., \& Wong, J.-Y. (2014). Identifying Gender Differences in Destination Decision Making. Journal of Tourism and Recreation, 1(1), 1-11. https://doi.org/10.12735/jotr.v1i1p01

Luturlean, B. S., Hurriyati, R., Wibowo, L. A., \& Anggadwita, G. (2018). Influencing factors in customers' intention to re-visit resort hotels: The roles of customer experience management and customer value. In Management Science (pp. 191-207). https://doi.org/10.1007/978-3-31959282-4_12

Maathuis, O., Rodenburg, J., \& Sikkel, D. (2004). Credibility, Emotion or Reason? Corporate Reputation Review, 6(4), 333-345. https://doi.org/10.1057/palgrave.crr.1540003

Mcenally, M., \& Chernatony, L. De. (1999). The Evolving Nature of Branding: Consumer and Managerial Considerations. Academy of Marketing Science Review. 
https://doi.org/http://citeseerx.ist.psu.edu/viewdoc/summary?doi=10.1.1.197.1211

Mulyanegara, R. C., Tsarenko, Y., \& Anderson, A. (2009). The Big Five and brand personality: Investigating the impact of consumer personality on preferences towards particular brand personality. Journal of Brand Management, 16(4), 234-247. https://doi.org/10.1057/palgrave.bm.2550093

Ohanian, R. (1990). Construction and validation of a scale to measure celebrity endorsers' perceived expertise, trustworthiness, and attractiveness. Journal of Advertising, 19(3), 39-52. https://doi.org/10.1080/00913367.1990.10673191

Park, C. W., Macinnis, D. J., Priester, J., \& Eisingerich, A. B. (2010). Brand Attachment and Brand Attitude Strength: Conceptual and Empirical Differentiation of Two Critical Brand Equity Drivers. Journal of Marketing, 74(6), 1-17. http://www.atyponlink.com/AMA/doi/abs/10.1509/jmkg.74.6.1

Park, W. C., MacInnis, D. J., \& Priester, J. (2006). Brand Attachment: Constructs, Consequences, and Causes. Foundations and Trends in Marketing, 1(3), 191-230.

Poon, W. C., \& Low, K. (2005). Are travellers satisfied with Malaysian hotels? International Journal of $\begin{array}{llll}\text { Contemporary Hanagement, } & \text { Hospitality } & \text { 217-227. }\end{array}$ https://doi.org/10.1108/09596110510591909

Rahman, M. T. (2019). Consumer Decision Making Style - Male Versus Female: A Study on Chattogram City, Bangladesh. Asian Journal of Social Science Studies, 4(2), 18. https://doi.org/10.20849/ajsss.v4i2.603

Rosli, N., Che-Ha, N., \& Ghazali, E. M. (2018). Gender Differences in Hotel Choice: A Case of Malaysian Muslim. International Journal of Engineering \& Technology, 7(4.28)), 312-316.

Rosli, N., Che-Ha, N., \& Ghazali, E. M. (2020). The influence of hotel attributes on brand attachment and post-consumption outcomes: The mediating effects of brand credibility. International Journal of Business and Society, 21(1), 313-333.

Rosli, N., Che Ha, N., \& Ghazali, E. M. (2019). Bridging the gap between branding and sustainability by fostering brand credibility and brand attachment in travellers' hotel choice. Bottom Line, 32(4), 308-339. https://doi.org/10.1108/BL-03-2019-0078

Saad, H. E., Ali, B. N., \& Abdel-Ati, A. M. (2014). Sharia-Compliant Hotels in Eygpt: Concept and Challenges. Advances in Hospitality and Tourism Research (AHTR), 2(1), 1-15.

Sallam, M. A. A., \& Wahid, N. A. (2012). Endorser Credibility Effects on Yemeni Male Consumer's Attitudes towards Advertising, Brand Attitude and Purchase Intention: The Mediating Role of Attitude toward Brand. International Business Research, 5(4). https://doi.org/10.5539/ibr.v5n4p55

Shafaei, F., \& Mohamed, B. (2015). Involvement and brand equity: a conceptual model for Muslim tourists. International Journal of Culture, Tourism and Hospitality Research, 9(1), 54-67. https://doi.org/10.1108/IJCTHR-06-2014-0050

Sheeraz, M., Khattak, A. K., Mahmood, S., \& Iqbal, N. (2016). Mediation of Attitude toward Brand in the Relationship between Service Brand Credibility and Purchase Intentions. Pakistan Journal of Commerce and Social Sciences, 10(1), 149-163.

Tae, H. B., \& King, K. W. (2011). Exploring the consequences of brand credibility in services. Journal of Services Marketing, 25(4), 260-272. https://doi.org/10.1108/08876041111143096

Tang, Y., Wang, X., \& Lu, P. (2014). Chinese consumer attitude and purchase intent towards green products. Asia-Pacific Journal of Business Administration, 6(2), 84-96. https://doi.org/10.1108/APJBA-05-2013-0037

Tanha, M. A. (2020). Exploring the credibility and self-presentation of insta micro-celebrities in influencing the purchasing decisions of Bangladeshi users. SEARCH (Malaysia), 12(2), 1-20.

Thomson, M., Macinnis, D. J., \& Park, C. W. (2005). The Ties That Bind: Measuring the Strength of Consumers 'Emotional Attachments to Brands. 15(1), 77-91.

Thomson, M., MacInnis, D. J., \& Park, C. W. (2005). The Ties That Bind: Measuring the Strength of Consumers' Emotional Attachments to Brands. Journal of Consumer Psychology, 15(1), 77-91. https://doi.org/10.1207/s15327663jcp1501_10

Thomson Reuters. (2017). State of Global Islamic Finance Report 2016/17. https://doi.org/10.1017/CBO9781107415324.004

Tsung, W. W., Day, R. L., \& Mackay, D. B. (1988). Consumer Benefits versus Product Attributes: An Experiemental Test. Quaterly Journal of Business and Economics, 27(3), 88-113. 
DOI: https://doi.org/10.47405/mjssh.v6i11.1159

Vlachos, P. A., Theotokis, A., Pramatari, K., \& Vrechopoulos, A. (2010). Consumer-retailer emotional attachment. European Journal of Marketing, 44(9/10), 1478-1499. https://doi.org/10.1108/03090561011062934

Wang, X., \& Yang, Z. (2010). The Effect of Brand Credibility on Consumers' Brand Purchase Intention in Emerging Economies: The Moderating Role of Brand Awareness and Brand Image. Journal of Global Marketing, 23(3), 177-188. https://doi.org/10.1080/08911762.2010.487419

Wilborn, L. R., Brymer, R. A., \& Schmidgall, R. (2007). Ethical Decisions and Gender Differences of European Hospitality Students. Tourism and Hospitality Research, 7(3-4), 230-241. https://doi.org/10.1057/palgrave.thr.6050055

Wuest, B. E. S., Tas, R. F., \& Emenheiser, D. A. (1996). What Do Mature Travelers Perceive as Important Hotel/Motel Customer Services? Journal of Hospitality \& Tourism Research, 20(2), 77-93. https://doi.org/10.1177/109634809602000206

Yang, S., Isa, S. M., Ramayah, T., Blanes, R., \& Kiumarsi, S. (2020). The Effects of Destination Brand Personality on Chinese tourists' Revisit Intention to Glasgow: An Examination across Gender. Journal of International Consumer Marketing, 32(5), 435-452. https://doi.org/10.1080/08961530.2020.1717400

Zloteanu, M., Harvey, N., Tuckett, D., \& Livan, G. (2018). Digital identity: The effect of trust and reputation information on user judgement in the sharing economy. PLoS ONE, 13(12). https://doi.org/10.1371/journal.pone.0209071 